Published in final edited form as:

Adv Drug Deliv Rev. 2008 January 14; 60(2): 263-276.

\title{
Cell Therapy for Spinal Cord Regeneration
}

\author{
Stephanie M. Willerth ${ }^{1}$ and Shelly E. Sakiyama-Elbert ${ }^{1,2,{ }^{*}}$ \\ 1 Department of Biomedical Engineering, Washington University in St. Louis \\ 2 Center for Materials Innovation, Washington University in St. Louis
}

\begin{abstract}
This review presents a summary of the various types of cellular therapy used to treat spinal cord injury. The inhibitory environment and loss of axonal connections after spinal cord injury pose many obstacles to regenerating the lost tissue. Cellular therapy provides a means of restoring the cells lost to the injury and could potentially promote functional recovery after such injuries. A wide range of cell types have been investigated for such uses and the advantages and disadvantages of each cell type are discussed along with the research studying each cell type. Additionally, methods of delivering cells to the injury site are evaluated. Based on the current research, suggestions are given for future investigation of cellular therapies for spinal cord regeneration.
\end{abstract}

\section{Keywords}

embryonic stem cells; neural stem cells; spinal cord injury; regenerative medicine; bone marrow stromal cells; biomaterials

\section{Introduction}

Less than $1 \%$ of people who sustain significant injury to their spinal cord recover complete neurological function and many of these injuries result in partial or complete paralysis. The three most common causes of spinal cord injury (SCI) include motor vehicle accidents, falls, and gunshot wounds. The number of people in the United States who currently live with SCI is estimated to be around 253,000 with 11,000 new cases occurring each year. The cost of lifetime care for one patient with SCI ranges from $\$ 700,000$ to $\$ 3,000,000$ [1]. Thus, a need exists for the development of therapies for treatment to ease both the physical and financial burdens of people who are afflicted with SCI. Many of the current strategies for treatment of SCI involve replacing the cells lost to injury with cells derived from an alternative source. The end goal of such treatments is to help restore function that was lost to the injury. In preclinical studies, such recovery is usually evaluated in the context of rodent models of SCI with the most promising strategies being translated to primate models. Such studies lay the groundwork for future clinical trials.

This review seeks to describe the present state of cell therapy for spinal cord injury. First, the obstacles to regeneration present in the injury site as well as the issues involved in cell sourcing are detailed. Next, the different types of cell therapy are defined with the benefits and

\footnotetext{
* To whom correspondence should be addressed: Shelly Sakiyama-Elbert Department of Biomedical Engineering Washington University Campus Box 1097 One Brookings Drive St. Louis, MO 63130 Telephone: (314) 935-7556 Fax: (314) 935-7448 sakiyama@ wustl.edu

Publisher's Disclaimer: This is a PDF file of an unedited manuscript that has been accepted for publication. As a service to our customers we are providing this early version of the manuscript. The manuscript will undergo copyediting, typesetting, and review of the resulting proof before it is published in its final citable form. Please note that during the production process errors may be discovered which could affect the content, and all legal disclaimers that apply to the journal pertain.
} 
drawbacks of each type given. Methods for delivering cells are also discussed. Finally, suggestions are made for future work in developing therapies for SCI.

\section{Considerations for developing cell therapy for spinal cord regeneration}

To successfully treat SCI by promoting functional recovery, cellular therapies must integrate into the injury site and restore the lost neuronal circuitry or promote plasticity of the spared neurons. To achieve this goal, cellular therapies should be designed considering both the obstacles posed by the injury site as well as sourcing and reproducibility issues associated with different cell culture systems.

\subsection{Obstacles to regeneration presented by the injured spinal cord}

SCI initiates a chain of events that lead to cell death, scarring and the loss of function. The initial trauma injures cells and induces swelling. The damaged cells release toxins that cause necrosis of the cells above and below the injury site. The lesion site that results from SCI poses many obstacles to promoting regeneration. Subsequent events include the formation of a cystic cavity at the injury site, which becomes surrounded by a glial scar, composed of mainly reactive astrocytes [2]. The demyelination that occurs after injury produces several inhibitory molecules that contribute to the lack of regeneration [3-5]. This section will address these obstacles in more depth and offer suggestions for creating a more permissive environment for regeneration following SCI.

2.1.1 Cavity formation-After the initial injury and following necrosis, a fluid filled cavity develops, resulting in the loss of grey and white matter [6]. The cavity can expand to additional spinal cord segments preceding and following the injury site, causing additional cell death and increased loss of function. Formation of the cystic cavity generates a physical barrier to spontaneous regeneration. Cell therapy can help overcome this barrier through a variety of methods. Implantation of neurons or cells that can differentiate into neurons could potentially bridge the lesion and restore signaling in the spinal cord. Other types of cells can secrete factors that promote regeneration of the damaged axons into the cavity while also providing the trophic support necessary for cell migration. Such strategies have demonstrated that reduction of the cavity size correlates with an increase in functional recovery $[7,8]$.

2.1.2 Glial scar formation and its inhibitory nature-Many different types of cells, such as macrophages, oligodendrocyte precursors, and meningeal cells, migrate to the injury site at different time points following injury. However, the resulting glial scar that forms consists of predominantly reactive astrocytes [2]. The astrocytes are densely packed and secrete inhibitory molecules into their extracellular matrix, making it difficult for injured neurons to regenerate across the injury site. The main class of inhibitory molecules produced by reactive astrocytes is chondroitin sulfate proteoglycans (CSPGs) [9]. These molecules have been shown to inhibit axonal regeneration in 3-D settings similar to those found in glial scarring [10]. One of the CSPGs responsible for inhibition of axonal migration is N2, which blocks the neurite extension promoting effects of laminin found in the extracellular matrix $[10,11]$.

Cell therapy addresses some of these barriers produced by the glial scar. Transplanted cells can secrete extracellular matrix and cytokines that promote cell migration to help provide counterbalance to the inhibitory effects of the glial scar. Such strategies can also lessen the amount of scarring present. Additional strategies for eliminating inhibitory CSPGs, which could also affect the migration of transplanted cells, include the use of molecules that prevent CSPG synthesis and chondroitinases which degrade the CSPGs in vivo [10,12]. These strategies can be combined with cell transplantation to create effective regeneration strategies. 
2.1.3 Myelin Based Inhibitors-Other major obstacles present after SCI include myelin based inhibitors such as Nogo, myelin based glycoprotein (MAG), oligodendrocyte myelin glycoprotein (OMgp) and tenascin, which are released by damaged oligodendrocytes [3,5,13, 14]. Nogo-A, the predominant isoform expressed in the CNS, consists of two transmembrane domains and one extracellular domain and inhibits neurite outgrowth [15]. This extracellular domain contains 66 amino acids and by itself can be used as an agonist referred to as Nogo-66 [3]. Other inhibitors present after SCI include MAG and OMgp. These three proteins (NogoA, OMgp, and MAG) all bind to the Nogo receptor, which mediates the inhibition of neurite outgrowth by signaling through Rho kinase. These proteins can be neutralized through the use of Nogo specific antibodies, such as the monoclonal antibody IN-1 [16], agonists such as Nogo-66 [3], using enzymatic removal of the receptor [17] or by knocking down expression of the Nogo receptor that binds these proteins [18]. Sialidase, which removes the glycan binding domains of MAG, has also shown promise for enhancing axonal outgrowth after injury [19]. Tenascin-R, an extracellular matrix glycoprotein, contributes to the inhibitory environment present after SCI. Multiple studies have demonstrated its effects on preventing neurite outgrowth and restricting motor neuron innervations after injury [20,21]. Tenascin-R deficient mice showed improved functional recovery after SCI compared to wild type mice, suggesting that knocking down its expression could be used as a therapeutic intervention. Thus, a combination of genetic manipulation and antibodies can be used to address the inhibitory proteins produced by the damaged oligodendrocytes.

\subsection{Challenges in developing cellular therapies to treat spinal cord injury}

The spinal cord possesses a complex architecture, composed of neurons, oligodendrocytes, and astrocytes. The careful arrangement of the different tracts of the spinal cord allow for a variety of information to be transmitted throughout the body. The different cell types and spatial arrangement of the spinal cord present challenges when trying to replicate the structure through the use of transplanted cells. This section will address the issues associated with developing cellular therapies for the treatment of SCI.

2.2.1 Cell Sourcing Issues-To successfully develop cell based therapies, many cell sourcing issues need to be considered. When developing such a strategy, the first consideration is how the cells will be obtained and the quantity of cells needed for transplantation. If the cells are obtained from an animal source for preclinical studies, thought should be given into how to translate such work to humans for clinical studies. For cells isolated from tissue, care should be taken to characterize the cells obtained to determine which specific cell phenotypes are being implanted. For studies examining the effects of implanting subpopulations of isolated cells, it is important to ensure the purity of the cells for implantation to later allow determination of how specific cell types contribute to regeneration. For many stem cell lines, issues arise when the cells are continuously cultured, including the reproducibility of the cell lines and number of times a cell line can be passaged. In particular, the properties of stem cells can vary with passage number. Other issues associated with human embryonic stem cell lines include the use of culture systems that rely on serum or feeder cell layers. There is a need for development of culture methods for human stem cells that involve chemically defined media. Such advances will allow for human stem cells to be transplanted in clinical trials with fewer regulatory issues.

2.2.2 Transplantation Issues-Once appropriate cell sourcing has been obtained, many different issues associated with cell transplantation must be considered. The first issue is how the cells will be delivered and common methods of transplantation will be discussed later in this review. The cell transplantation method should ensure the integrity and viability of the cells. For progenitor cells, care should be taken to ensure that the delivery method does not induce unwanted differentiation or proliferation, which can lead to formation of tetratomas. 
For cross species transplantation, such as mouse cells or human cells being transplanted into rat injury models, the issues of immune response should be addressed by treating the animals with appropriate immunosuppressants. The end goal for cellular therapies would be to create cell lines for transplantation that do not require immune suppression of the patient. Other issues to consider are the location of the cells after transplantation and how to control cell differentiation, proliferation and migration in the injury sites. Uncontrolled proliferation can lead to the formation of tetratomas after implantation, which is undesirable. One delivery method that can address the issue of controlling cell differentiation and migration is through the use of biomaterial scaffolds which are discussed later in this article [22-26].

\section{Types of Cellular Therapy}

A variety of cell types have been evaluated in the context of SCI. Each section will summarize the advantages and disadvantages of each cell type and discuss the studies performed. Table One lists the cell types discussed in this review along with the references associated with each cell type. Unless specifically mentioned, these cellular therapies are evaluated in the context of rat models of SCI. The most common assessment of functional recovery in these models is the Basso, Beattie, and Bresnahan (BBB) scale for assessing locomotor behavior [27]. Additional methods of assessing functional recovery include having the animals perform specific tasks, such as tape removal or rope walking and sensory recovery, such as response to thermal and mechanical stimuli.

\subsection{Embryonic stem cells}

Embryonic stem cells (ESCs), which are derived from the blastocyst, possess two important properties: pluripotency and the ability to self renew. Their ability to differentiate into cells from all three germ layers make them an attractive source for a variety of applications [28-30]. Some of the challenges in using ESCs include determining the correct cues to direct differentiation in the specific desired cell types in vitro and in vivo and preventing tetratoma formation [31]. Many of these differentiation protocols involve formation of aggregates of cells known as embryoid bodies (EBs) and treatment with growth factors [23,32-34].

3.1.1 Mouse embryonic stem cells-Mouse ESCs have been investigated as a starting point for developing potential therapies for SCI. These cells are attractive for preclinical studies because they are easy to culture and readily differentiate into the cells found in the CNS. Many different mouse ES cell lines exist and these lines can be studied with federal funding in the United States. Often, mouse ESCs are tested in the context of rat models of SCI, allowing the implanted cells to be distinguished from the host cells. However, immunosupression is necessary to prevent rejection of these cells by the host immune system.

One of the first studies that looked at using mouse ESCs for treatment of spinal cord injury involved a multistep process that promoted the formation of oligodendrocytes and astrocytes for transplantation [35]. Once transplanted into the spinal cord, these cells demonstrated the ability to restore myelination in myelin-deficient shiverer rats, indicating the potential of mouse ESCs to treat SCI.

This work was followed by a pair of studies performed by the McDonald lab that looked at the ability of mouse ESCs treated with retinoic acid to promote recovery in SCI models $[34,36]$. In the first study, the cells were grown as 4-/4+ retinoic acid treated EBs [33], partially dissociated and injected nine days after contusion injury [36]. These cells differentiated into mainly oligodendrocytes and astrocytes and were able to promote an increase in BBB scores. The second study focused on producing oligodendrocytes from mouse ESCs for remyelination therapy [34]. The first part of the study determined a set of culture conditions to produce mainly oligodendrocytes from the mouse ESCs. These oligodendrocytes were demonstrated to 
remyelinate axons both in vitro and in an in vivo model consisting of chemically induced demyelination in the spinal cord.

Other studies have demonstrated that mouse ESCs can survive in the spinal cord for more than 50 days, suggesting their potential as a long term treatment for SCI [37]. A more recent study showed that mouse ESCs pretreated with a lecithinized brain derived neurotrophic factor (BDNF) implanted 9 days after T9/10 contusion injury showed better differentiation and promoted increased functional recovery afterwards, as assessed by BBB compared to cells treated with normal BDNF, demonstrating the influence of growth factor treatments on ESC differentiation [38]. Mouse ESCs predifferentiated using the 4-/4+ protocol were implanted after 7 days into a chronic pain SCI model that consisted of repeated microinjections of quisqualic acid between T13 and L1 [39]. These cells helped relieve chronic pain as indicated by reduction in excessive grooming behavior and increased sensitivity to other thermal and mechanical stimuli.

Recent work has looked at different types of genetically modified mouse ESCs and their impact on SCI. Mouse ESCs were modified to overexpress the bcl-2 protein, which blocks apoptosis, and implanted 9 days after contusion injury [40]. However, these cells did not produce an increase in functional recovery and resulted in tumor-like growths. This study illustrates the importance of selecting the appropriate proteins when genetically modifying cells for transplantation. Another study examined the effect of transfecting mouse ESCs with the L1 adhesion molecule, which promotes neuronal outgrowth, to determine the effect on cell behavior [41]. These cells were injected both rostrally and caudaully to the injury site 7 days after a T7-9 compression injury. After one month, the cells transfected with L1 showed increased survival and migration compared to untransfected ESCs. Overall, mouse ESCs serve a model cell culture system for determining effective strategies for treatment of SCI due to the ease of culture and ability to be genetically modified. These strategies provide a starting place for translating such methods to human ESCs.

3.1.2 Human embryonic stem cells-Development of methods and strategies for using human ESCs for treatment of SCI allows for translation to clinical studies. One of the challenges of developing human ESC therapies is determining the necessary cues to promote differentiation in the desired cell types, such as oligodendrocytes and motor neurons. Although the work done with mouse ESCs provides a good starting point, the end goal is to determine human ESC differentiation protocols. Similar to the mouse ESCs, testing the ability of human ESCs to promote recover in rat injury models requires immunosupression. Many of the human ESC lines that currently exist have been cultured in the presence of mouse feeder cell layers, making them undesirable for use in clinical trials. Other major challenges include developing person specific ESC lines to allow transplantation without immunosupression in a clinical setting.

Work from the Keirstead lab has focused on developing protocols that produce large numbers of oligodendrocytes from human ESCs [42-45]. Their time intensive differentiation protocol involves multiple selection steps with serum free media to produce oligodendrocyte progenitor cells (OPCs) that can differentiate into mature oligodendrocytes in vitro and in vivo [42]. They implanted these cells into myelin deficient shiverer mice where they integrated into the spinal cord, differentiated into oligodendrocytes and restored myelination. Based on these results, they investigated transplanting these human ESC-derived OPCs 7 days after T10 contusion injury [43]. They demonstrated that these cells differentiated into mature oligodendrocytes in vivo that could remyelinate damaged axons. An increase in BBB scores for animals that received the OPCs was observed compared to animals that received media only and injured control animals. Further studies indicated that such a strategy for treatment of SCI is only successful when extensive demyelination induced by a $200 \mathrm{kD}$ contusion injury is present, but 
not for a $50 \mathrm{kD}$ injury that does not induce demyelination [45]. Another study has investigated differentiating human ESCs into neurons for use as a therapy for SCI [32]. This study determined a protocol for producing large numbers of motor neurons from human ESCs. These cells were able to maintain their phenotype after in vivo transplantation into the adult rat spinal cord. This study demonstrate the potential to create human ESC derived neurons, but these cells still need to be further characterized to determine how they will integrate and contribute to functional recovery after SCI.

\subsection{Neural stem cells}

Neural stem cells (NSCs) refer to the multipotent stem cells that give rise to the cells of the nervous system. These cells are self renewing and are often cultured as neurospheres. They are found in both embryonic and adult tissues. NSCs isolated from the central nervous system (CNS) also have been explored as a potential therapy for SCI. Figure 1 shows a schematic of how NSCs could potentially promote recovery after SCI through different mechanisms. The majority of the studies use NSCs derived from embryonic animal tissue, usually mouse or rats. Unless specifically mentioned otherwise, embryonic NSCs were isolated from the CNS of rats on day 14 of embryonic development. Unlike ESCs, these cells are limited to becoming neurons, oligodendrocytes, and astrocytes, making it easier to achieve differentiation into the desired cell types. For many of the studies, the NSCs were harvested from the same species of animal that they were then transplanted back into to eliminate the possibility of rejection. This method of harvesting embryonic NSCs poses a problem for clinical studies since these methods cannot be replicated ethically in humans. Adult NSCs provide an important alternative to embryonic NSCs and could potentially be obtained from a patient or cadaver to be transplanted into their injured spinal cord, making them attractive from a clinical perspective.

In one of the first studies using rat embryonic NSCs, Cao et al. investigated implanting NSCs into both normal and lesioned (T8 contusion) spinal cord [46]. They found the majority of the implanted cells differentiated into astrocytes, suggesting that these cells may need to be predifferentiated before implantation [47]. Further work demonstrated that factors present after SCI restrict differentiation of these cells. To try and overcome some of these signals, specifically bone morphogenetic protein (BMP), NSCs were engineered to express noggin, a BMP agonist, to attempt to obtain better differentiation into neurons and oligodendrocytes [48]. This strategy was unsuccessful at preventing differentiation and these cells actually produced an increase in lesion size. However, a different study successfully implemented this strategy and achieved differentiation of NSCs expressing noggin into neurons and oligodendrocytes after being implanted into a T8 contusion injury as well as promoted an increase in BBB scores 3 weeks after injury [49]. These studies illustrate the importance of controlling protein expression levels when performing genetic manipulation.

Other studies have used NSCs in combination with other strategies to treat SCI. The Langer lab seeded mouse NSCs into polymer scaffolds [25]. These scaffolds were then implanted into the lesion site resulting from a T9/10 lateral hemisection. This approach produced functional recovery as indicated by an increase in BBB scores after 3 weeks compared to animals receiving only cells and the lesion only animals. This increase in recovery was observed throughout the rest of the 10 week study even though the transplanted cells did not stain positive for mature cell markers, indicating that they remained undifferentiated. Tuszynski and colleagues confirmed that mouse NSCs constitutively secrete a variety of growth factors, including nerve growth factor (NGF), BDNF, and glial-derived neurotrophic factor (GDNF), in vitro and in vivo [50]. In vivo, the transplanted NSCs promoted axonal sprouting in a $\mathrm{C} 3$ hemisection injury. They then genetically modified these NSCs to produce neurotrophin-3 (NT-3), which when tested in the same in vivo model, enhanced the axonal sprouting that was previously observed. Another approach combined NSC transplantation with antibodies that neutralize the effects of 
ciliary neurotrophic factor (CNTF) [51]. This study showed that neutralizing CNTF reduced the amount of NSCs that differentiated into astrocytes while promoting regeneration of the corticospinal tract. No behavioral analysis was reported for this study. A different study by the Schwartz lab looked at transplanting adult NSCs 7 day post injury in combination with myelin specific T cells to determine the effect on SCI in a mouse model (T12 contusion injury) [52]. The combination of cells was able to produce functional recovery as evidenced by an increase in the Basso mouse scale (BMS) [53].

The Weidner group has studied the use of rat adult neural progenitor cells (NPCs) as a therapy for treating SCI. One of their studies looked at the differentiation of these cells both in vitro and in vivo [54]. In vitro, the adult NPCs differentiated into mostly neurons and oligodendrocytes with few astrocytes present. These NPCs were then tested in vivo by transplanting them immediately following a C3 dorsal column transaction injury. These cells did not have any effect on the lesion size, but did colocalize with the axons of the corticospinal tract. A follow up study showed that transplanting these NPCs along with fibroblasts produced an increase in axonal regeneration compared to transplanting only fibroblasts into the injury site [55].

Several studies have investigated the potential of NSCs derived from humans to promote recovery in animal models of SCI. One of the first studies looked at the ability of human NSCs derived from fetal brain cultured as neurospheres to promote recovery after T9 contusion injury in both severe combined immunodeficiency (SCID) and myelin-deficient shiverer mice [56]. These cells differentiated into functional neurons and oligodendrocytes while promoting an increase in functional recovery as assessed by BBB scores. Additional work confirmed the increase in recovery was due to the NSCs [57]. Another study looked at priming human NSCs derived from fetal tissue with a combination of growth factors to induce preferential differentiation towards cholinergic neurons [58]. After transplantation into the spinal cord, these cells were able to differentiate into cholinergic neurons whereas the same cells that were not treated with the growth factors differentiated into astrocytes. A different study looked at the effect of implanting human NSCs into a C5 contusion injury in marmosets [59]. The NSCs differentiated into neurons, oligodendrocytes, and astrocytes while promoting an increase in hand grip and motor activity compared to control animals. Finally, Tarasenko and colleagues tested the effects of priming human NSCs with a combination of heparin, laminin and FGF to determine if it would affect in vivo differentiation [60]. The cells that were primed demonstrated increased viability after transplantation into rats compared unprimed cells. Although no differences were observed in BBB scores between groups, the animals receiving the primed cells showed an increase in trunk stability as assessed by rearing activity.

\subsection{Bone marrow stromal stem cells}

Bone marrow stromal cells (BMSCs) are multipotent progenitor cells obtained by taking the heterogeneous cell population found in bone marrow and selecting for the adherent subpopulation. Rat and human BMSCs can differentiate into cells that express markers for mature neuronal cells [61-63], but later studies indicate that these cells do not express voltage gated ion channels [64]. From a clinical perspective, BMSCs are attractive for transplantation because they are easily obtained from bone marrow and can be transplanted back into the original donor, eliminating the risk of rejection. Hofstetter et al. transplanted BMSCs into T7 contusion injury model of SCI both immediately following injury and 7 days post injury [64]. The cells transplanted 7 days post injury showed better rates of survival and formed bundles that bridged the lesion. Implantation of BMSCs also led to an increase in BBB scores compared to controls. Another study showed coculture of BMSCs along with NSCs obtained from the spinal cord promoted differentiation of the NSCs into neurons and glia in vitro [8]. In vivo transplantation of BMSCs immediately after T8/9 contusion injury reduced cavity formation 
and also promoted an increase in BBB scores. The authors suggest that the BMSCs provided trophic factors and support for the cells present in the injured spinal cord, allowing them to migrate into the injury site. Similar results were obtained by a different group when BMSCs were infused in the cerebrospinal fluid (CSF), providing an alternate method of delivery [7]. Other studies have also looked at the feasibility of different methods of intravenous injection for BMSC delivery [65-67], but a study by Vaquero et al. showed that direct injection of BMSCs into the site of a T6-8 contusion injury promoted superior functional recovery when compared to intravenous injections of BMSCs [68]. A long term study by the Vaquero lab looked at the long term effects of transplanting BMSCs 3 months after a crush injury [69]. This study showed that functional recovery steadily increased over the course of a year as indicated by BBB scores. Finally, human BMSCs transplanted into a T9 contusion model of SCI also promoted functional recovery as indicated by BBB scores, suggesting that this therapy has potential to work in humans [70].

Additional work has been done to clarify the mechanisms by which BMSCs promote functional recovery. One study demonstrated that BMSCs help guide regenerating axons across the injury site when implanted 2 days after a T8 contusion injury and can help promote recovery by restoring the stepping control circuitry [71]. A more recent study showed that BMSCs express the gamma aminobutyric acid (GABA receptor) [72]. They implanted BMSCs rostrally to the lesion 7 days after a T10/11 impact injury. However, in this study, functional recovery as assessed by the BBB scale was not observed 4 weeks after injury. BMSCs stimulate phosphoinositide-3-kinase and mitogen-activated protein kinase signaling in neurons, which promotes their survival [73].. All of these mechanisms contribute to the success of BMSC transplantation as a treatment for SCI.

A pair of studies from the Tuszynski lab investigated the use of BMSCs that were genetically modified to express growth factors to treat a dorsal column transaction injury at $\mathrm{C} 3[74,75]$. The first study looked at the effects of transplanting BMSCs that secreted BDNF immediately following injury. The BDNF expressing cells induced more robust axonal growth into the lesion site compared to normal BMSCs [74]. Functional recovery, judged by a tape removal task and rope walking, was not observed. The second study examined the ability of BMSCs modified to express NT-3 to induce axonal growth through chronic glial scars [75]. These cells were implanted 6 weeks post injury at the $\mathrm{C} 3$ level and the scar was not resected. These cells were able to promote regeneration of axons through the scars and into the lesion site, demonstrating that the glial scar can be penetrated. These studies illustrate the additional benefits of genetic modification when used in combination with BMSCs.

\subsection{Other cell types}

In addition to progenitor cells, researchers have also investigated the use of terminally differentiated cells, such as Schwann cells, olfactory ensheathing cells (OECs), and fibroblasts, for the treatment of SCI. These cells are easily obtained and cultured, making them attractive for translational studies. Schwann cells could potentially be harvested autologously from peripheral nerves in manner similar to how nerves are harvested for isograft use in repair large gaps produced by injury to the PNS [76]. OECs can be obtained for autologous transplantation through nasal biopsies and grown in cell culture until needed [77]. Finally, fibroblasts can be isolated from skin and cultured in vitro to allow for genetic manipulation before transplantation [78]. These methods for harvesting and culture allow for transplantation without the issue of rejection. However, it often takes 2-4 weeks of in vitro cell culture to generate enough cells for transplantation.

3.4.1 Schwann cells-Schwann cells produce the myelin sheaths that surround the neurons of the peripheral nervous system (PNS) [79]. They play a key role in regenerating axons of the 
PNS after injury by converting to non-myelinating Schwann cells that secrete a variety of growth factors, including NT-3, NGF, BDNF, CNTF, and fibroblast growth factor (FGF). These cells also migrate to the injury site after SCI despite being part of the PNS [80]. These cells can be easily expanded in vitro, allowing for autologous cell transplantation to avoid immune response. Thus, Schwann cells have been studied for their potential to promote axonal regeneration and myelination after SCI $[81,82]$.

Bunge and colleagues investigated using Schwann cells seeded in Matrigel inside of nerve guidance conduits (NGCs) with the distal end capped to determine their effect on the injured spinal cord [83]. In this study, they used a complete transaction injury model, removing the spinal cord between T9-11 and replacing it with the NGCs containing Schwann cells. Compared to control conduits, the NGCs containing Schwann cells showed increased remyelination as well as propriospinal and sensory axonal regeneration. A follow up study combined this approach with delivery of BDNF and NT-3 from osmotic pumps [84]. This approach resulted in the regeneration of the supraspinal axons, but no assessment of functional recovery was reported. A third study indicated that using open ended channels with such an approach resulted in axonal regeneration from both the rostral and caudal ends of the injury [85]. Follow up studies using similar approaches demonstrated that the injured animals regained impulse conduction only after receiving the Schwann cells $[86,87]$. Finally, Schwann cells showed the ability to promote functional recovery as indicated by the BBB scores when used to treat a less severe injury (T8 contusion), showing their promise as a therapy for mild SCI [88].

Other studies have looked at genetically modifying Schwann cells to secrete increased amounts of growth factors, specifically NGF and BDNF [89-91]. Although the genetically modified cells promoted more axonal regeneration than unmodified Schwann cells, no functional recovery was observed with either cell line. Additionally, several studies have used Schwann cells in combination with other strategies for treatment of SCI. Chondroitinase ABC enhances Schwann cell-induced axonal regeneration, but it does not lead to functional recovery in T9 dorsal hemisection injury model [92]. Combining cyclic adenosine monophosphate (cAMP) with Schwann cells as therapy for treatment of a T8 mild contusion injury resulted in functional recovery as assessed by the BBB [93]. This study used an inhibitor against the phosphodiesterase that hydrolyzes cAMP to extend its signaling, which allows the neurons to extend into otherwise inhibitory substrates. These results suggest that Schwann cells work best when used in combination with other therapeutic approaches that minimize the inhibitory nature of the lesion site.

3.4.2 Olfactory ensheathing cells-Unlike the rest of the adult CNS, the olfactory bulb retains its regenerative capacity. Neurons found in the olfactory system last approximately 4 weeks before they die and are replaced by newly formed neurons. This difference is attributed to the presence of OECs, which are glial cells that direct the differentiation of progenitor cells present in the olfactory system [94]. These cells have been extensively investigated to see if they have the same capacity to promote regeneration following SCI. These cells can be harvested and then transplanted back into the original human donor, eliminating rejection. These cells can are easily obtained, making them ideal for translational research.

Raisman et al. demonstrated that OECs isolated from rats could be used to repair the corticospinal tract after injury at $\mathrm{C} 1 / 2$ as demonstrated by recovery of reaching behavior on the side of the lesion [95]. Follow up studies showed that these cells induced myelination, which allowed for this recovery [96]. They later repeated this work in a chronic SCI model. In that study, the cells were implanted 8 weeks after injury and 1 to 3 weeks later, the animals receiving the cells demonstrated functional recovery [97]. 
Other groups confirmed similar findings when OECs were implanted in other types of injury models. After complete spinal cord transaction at T8/9, rats receiving OECs immediately after injury showed an increased ability to climb on grids 3 months following the surgery compared to untreated injured rats [98]. Similar results were obtained by other groups [99,100]. A different study investigated the use of human OECs obtained during surgery to remove frontal base tumors. These cells demonstrated that they could also remyelinate myelin-deficient immunosupressed rats, indicating that human OECs possess similar regenerative properties as the rat OECs [101].

More recent studies have investigated if other mechanisms, in addition to remyelination, were contributing to the ability of OECs to promote regeneration. One study showed that the presence of OECs helps mitigate the loss of tissue after photochemical (Rose Bengal) injury at T8 [102]. This study also observed functional recovery as indicated by BBB scores and measurement of sensory-evoked potentials. Similar results were observed by Bunge and colleagues when OECs were grafted 7 days post T8 moderate contusion injury [103]. They also saw regeneration of supraspinal axons.

Studies have also investigated the use of genetically modified OECs to see if additional benefit and recovery could be obtained. One study compared the effects of modifying OECs to secrete either NT-3 or BDNF [104]. The cells that expressed BDNF promoted recovery of the rubrospinal tract after $\mathrm{C} 3$ unilateral transaction injury compared to the cells that expressed NT-3 and control cells. The growth factor secreting OECs also promoted functional recovery as assessed by a rope walking task as compared to animals receiving unmodified OECs and control animals. A follow up study confirmed that the NT-3 secreting cells promoted tissue sparing in the same injury model, but no differences in functional recovery were observed between experimental and control groups [105]. OECs modified to secrete GDNF have also been shown to promote functional recovery after SCI [106]. In this study, OECs that secreted GDNF were implanted immediately following $\mathrm{T} 8$ transection injury. The animals receiving the GDNF secreting cells promoted increased BBB scores after 4 weeks and increased ability to walk up planes after 5 weeks compared to both animals that only received OECs and untreated injured animals. Currently, Phase I clinical trials using autologous OEC transplantation are underway in Australia where these cells have been demonstrated to be safe for up to one year after treatment [77].

3.4.3 Fibroblasts-Fibroblasts are cells that make up connective tissue and secrete extracellular matrix molecules, such as collagen and glycoproteins. These cells are also easy to obtain and expand in culture, making them attractive for use as a cellular therapy. Fibroblasts are also easy to genetically modify, allowing for additional functionality. However, the method of transfection should be carefully considered. Some transfection agents only produce transient expression of the target protein while other methods, such as lentiviral transfection, produce stable protein expression, but may cause unwanted mutations upon integrating into the chromosomal DNA of the fibroblasts. It is also important to characterize the rate at which these cells produce the target proteins as often there is a target range of therapeutic concentrations. Too little or too much protein expression can result in seeing no effect or negative effects on functional recovery.

Many studies have been performed to determine the effect of transplanting fibroblasts that overexpress neurotrophins, including NT-3, BDNF, and NGF. The Tuszynski lab and their colleagues have done extensive research into the use of genetically modified fibroblasts for treatment of SCI. Initially, they examined the effect of grafting fibroblasts modified to secrete NT-3 acutely into a T7 dorsal hemisection model. These cells produced increases in functional recovery as assessed by a grid walk test compared to unmodified fibroblasts and fibroblasts modified to secrete NGF [107]. They also evaluated the effects of grafting the NGF secreting 
fibroblasts into a primate model of SCI. In that study, the spinal cord was injured through multiple needle penetrations from T7- T9 followed by injections of the fibroblasts. The grafts promoted secretion of extracellular matrix molecules, such as L1, and increased cell migration into the injury sites, but no data about the effect on functional recovery was reported [108]. They also studied the effects of implanting these cells into a variety of lesion types and determined that they could promote axonal regeneration through the CSPG-rich areas of the glial scar [11].

A pair of studies looked at the effects of delayed transplantation of two types of fibroblasts, one set that expressed NT-3 and one set that expressed BDNF $[109,110]$. The first study looked at the physiological effects of implanting these cells 6 weeks after complete transection of the spinal cord between the C3 and C4 segments [109]. They observed that the growth factorsecreting grafts promoted axonal growth into the injury site compared to unmodified fibroblasts and rescued red nucleus neurons. The second study looked at the effects of transplanting these cells on functional recovery through a variety of assessments including BBB scoring, grid walk, mechanical and heat sensitivity tests [110]. The BBB scores actually decreased following implantation of the cells, suggesting that the additional surgery reinjured the spinal cord. The experimental group receiving the growth factor-secreting cells did showed increased sensitivity to heat compared to the control animals.

Many other groups have also investigated the use of fibroblasts as a potent treatment for SCI. McTigue et al. investigated the effects of several growth factors, including NT-3, BDNF, CNTF, NGF and basic FGF, secreted by genetically modified fibroblasts on regeneration after SCI [111]. The cells modified to secrete NT-3 and BDNF promoted proliferation of endogenous oligodendrocytes and remyelination of damaged axons.

Other studies have looked at the effect of modifying fibroblasts to express other proteins that may have therapeutic benefits for the treatment of SCI. Blesch and Tuszynski investigated the effects of implanting cells that secrete GDNF immediately after T7 dorsal hemisection injury. These cells promoted regeneration of the dorsal sensory column, propriopsinal and motor axons, but functional recovery was not observed [112]. Another study looked at grafting fibroblasts that secreted neurotrophin- $4 / 5$ into hemisection and complete transaction injuries at T8 [113]. These cells promoted robust axonal regeneration and Schwann cells were able to infiltrate the grafts. However, no functional recovery as assessed using the BBB scale was observed compared to control animals that only received green fluorescent protein expressing cells. A third study looked at the effects of transplanting fibroblasts that produce matrix metalloproteinase-3 into T7 contusion injury [114]. They hypothesized that these cells would degrade the inhibitory CSPGs present at the injury site, allowing for enhanced regeneration. These cells promoted increased serotonergic fibers distal to the injury site and functional recovery compared to unmodified fibroblasts but not to control animals that did not receive cells. This study suggests that the transplantation process or the cells themselves used caused a decrease in functional recovery.

\section{Delivery methods for cellular therapy}

Once a decision has been made regarding what type of cells to use, the next consideration is how to deliver the cells to the injury site. Most of the studies discussed previously involved directly injecting the cells into and around the injury site. Other minimally invasive injection methods have been studied, such as intravenous injection, infusion into CSF, and lumbar puncture $[7,65,67,68]$. An alternative method of delivery involves seeding cells into scaffolds and then implanting the scaffolds into the injury site. This section will review these methods and their advantages and disadvantages will be discussed. 


\subsection{Injection}

The majority of studies use a variety of injection methods for delivery of cellular therapeutics. The most common method of cell grafting involves injecting cells to deliver them into and around the site of injury [68]. Many studies inject cells rostrally or caudally from the injury site to achieve better levels of survival. Direct injection into the injury site often produces poor results in terms of cell survival due to the harsh environment in the lesion. One of the main issues with using direct injection in the surviving tissues is minimizing the risk of further injury caused by performing a laminectomy which to allow access for injection. To overcome this issue, some studies have explored alternative methods of delivery. Systemic administration of BMSCs by injection into the tail veins of rats has been studied as a minimally invasive injection technique. Although cells delivered using this method were found at the injury site, direct injection of BMSCs into the injury site produced superior functional recovery [68]. Other injection methods include using lumbar puncture to deliver cells and injecting the cells into the CSF containing cavities found in the brain $[65,66]$. The first study investigated injecting BMSCs at L4-5 using a lumbar puncture method [65]. Administering this cellular therapy within 14 days of $\mathrm{T} 8$ contusion injury produced the best results including a reduction in cyst volume and injury size. Additionally, this method allows for multiple injections, which could be useful for treatment of chronic injuries. The second study examined injecting cells into the fourth ventricle of the brain, which consists of a cavity containing CSF [7]. These cells were injected at the time of T8 contusion injury and the presence of BMSCs promoted an increase in BBB scores 7 days after surgery compared to untreated, injury only control animals. This increase in scores was observed up to 35 days following the surgery. These minimally invasive methods show promise, but more research needs to be done to fully characterize the efficacy of these strategies compared to the direct injection method.

\subsection{Implantable scaffolds}

An alternative method for delivering cells to the injury site involves seeding cells into scaffolds and then implanting the scaffold into the injury. This method has several advantages over direct injection. One advantage is that scaffolds can provide a more hospitable environment for cell survival, as well as trophic support for cells. In some cases, these scaffolds can be modified to contain cues to promote cell survival and promote progenitor cell differentiation. A variety of materials have been evaluated for their use as scaffolds for treatment of SCI [22,26]. The Langer lab seeded NSCs into poly(lactic-co-glycolic) acid (PLGA) scaffolds before implanting them into a hemisection model of SCI where they promoted functional recovery as indicated by an increase of 4 on the BBB scale compared to animals that received cells only and untreated injury only animals [25]. The details of this scaffolding system are shown in Figure 2. The scaffold architecture was designed to mimic the arrangement of white and grey matter found in the uninjured spinal cord. More recent in vitro work from the Langer lab has investigated the use of scaffolds consisting of 50/50 blends of PLGA and poly L-lactic acid (PLLA) for promoting the differentiation of human ESCs into neuronal phenotypes [23,24]. These scaffolds have been used to promote neuronal differentiation by presenting such cues as retinoic acid and NT-3. Other groups have investigated using poly (ethylene glycol) (PEG) scaffolds seeded with rat NSCs to engineer neural tissue [115]. A follow up study indicated that bFGF enhanced NSC survival while scaffolds containing collagen did not have an observable effect on NSC behavior [116]. Our lab has evaluated fibrin scaffolds as a method for differentiating and delivering mouse ESCs [22]. Previous in vivo work has shown that controlled growth factor release from such scaffolds provides beneficial short term effects as a treatment for SCI [117-119]. Our most recent work evaluated the effect of different doses and combinations of growth factors on the differentiation of mouse ESCs seeded inside of 3D fibrin scaffolds [120]. Ongoing studies are currently being performed to test this approach in vivo. Additionally, Ma and colleagues have shown that rat embryonic NSCs form functional neuronal circuits when cultured inside of collagen scaffolds, showing promise an alternative scaffold material 
[121]. This research area, which combines scaffolds with cell transplantation, holds promise as an alternative to injection methods. Such scaffolds may enhance cell survival after transplantation and promote differentiation into desired phenotypes based on the scaffold properties.

\section{Conclusions and future directions}

This review has discussed the major issues associated with cell therapy for spinal cord regeneration, including obstacles presented by SCI, the different cell types available, and methods for cell transplantation. SCI presents many obstacles to regeneration and many of the strategies that achieve functional recovery take a multi-component approach. One of the multicomponent approaches involves transplanting two or more types of cells as therapy for SCI. These strategies can be successful because one cell line can provide secreted factors and trophic support for the second cell line. In addition to cells, protein therapy, such as the use of growth factors, enzymes, and neutralizing antibodies, helps promote regeneration after SCI. Of the growth factors tested experimentally, NT-3, BDNF, and GDNF show the most promise for SCI treatment. These growth factors can be delivered through genetic modification, osmotic pumps, or by drug eluting scaffolds. The last two methods (osmotic pumps and drug eluting scaffolds) can also be used to deliver enzymes, such as chondroitinase $A B C$, and neutralizing antibodies, such as $\alpha$-CNTF and $\alpha$-NogoR.

Cells genetically modified to secrete growth factors have the advantage of continuously providing an influx of protein. However, this benefit can turn into a disadvantage once healthy tissue has been restored. The presence of additional growth factor could lead to unwanted to cell proliferation. The Tuszynski lab has investigated the use of cells that secrete growth factor in response to tetracycline ingestion, thus controlling the rate of secretion [122]. Drug eluting scaffolds can only release the amount of growth factor that was loaded initially into the scaffold. The rate of release can be modulated through a variety of methods and the time course of release can be tailored to the time course of regeneration. This process eliminates the issue of unwanted growth factor present after regeneration has occurred.

Overall, cell therapy combined with other regeneration promoting strategies holds the most promise for restoring function after traumatic SCI. Many of these strategies have demonstrated efficacy in preclinical trials. For successful translation to the clinic, these strategies should be tested in chronic models of SCI and functional recovery should be assessed using a variety of tests, not just the BBB scale. Additionally, the development of embryonic and neural stem cell technology will require further research to produce both the cell lines and culture methods necessary for clinical trials as well as for producing patient specific stem cells. Recent studies have suggested that patient specific ESCs could be produced by dedifferentiating mature cells [123]. This research provides one potential avenue for translation of ESC therapies to clinical trials. Overall, cellular therapies hold great potential for the treatment of SCI.

\section{Acknowledgments}

Financial support for this work was provided by NIH R01 NS051454.

\section{Abbreviations}

$\mathrm{BBB}$, Basso, Beattie, and Bresnahan

BMS, Basso mouse scale

BMSCs, Bone marrow stromal cells

BMP, Bone morphogenetic protein

BDNF, Brain derived neurotrophic factor

CNS, Central nervous system 
CSF, Cerebrospinal fluid

CSPGs, Chondroitin sulfate proteoglycans

CNTF, Ciliary neurotrophic factor

cAMP, Cyclic adenosine monophosphate

EBs, Embryoid bodies

ESCs, Embryonic stem cells

FGF, Fibroblast growth factor

GDNF, Glial-derived neurotrophic factor

MAG, Myelin associated glycoprotein

NGF, Nerve growth factor

NGCs, Nerve guidance conduits

NPCs, Neural progenitor cells

NSCs, Neural stem cells

NT-3, Neurotrophin-3

OECs, Olfactory ensheathing cells

OMgp, Oligodendrocyte myelin glycoprotein

OPCs, Oligodendrocyte progenitor cells

PNS, Peripheral nervous system

PEG, Poly (ethylene glycol)

PLGA, Poly (lactic-co-glycolic) acid

PLLA, Poly (Llactic) acid

SCID, Severe combined immunodeficiency

SCI, Spinal cord injury

\section{References}

1. National Spinal Cord Injury Statistical Center Fact Sheet. National Spinal Cord Injury Center; Jun. 2006

2. Fawcett JW, Asher RA. The glial scar and central nervous system repair. Brain Res Bull 1999;49:37791. [PubMed: 10483914]

3. McGee AW, Strittmatter SM. The Nogo-66 receptor: focusing myelin inhibition of axon regeneration. Trends Neurosci 2003;26:193-8. [PubMed: 12689770]

4. Myckatyn TM, Mackinnon SE, McDonald JW. Stem cell transplantation and other novel techniques for promoting recovery from spinal cord injury. Transpl Immunol 2004;12:343-58. [PubMed: 15157926]

5. Busch SA, Silver J. The role of extracellular matrix in CNS regeneration. Curr Opin Neurobiol 2007;17:120-7. [PubMed: 17223033]

6. Greitz D. Unraveling the riddle of syringomyelia. Neurosurgical review 2006;29:251-63. [PubMed: 16752160]discussion 64

7. Ohta M, Suzuki Y, Noda T, Ejiri Y, Dezawa M, Kataoka K, et al. Bone marrow stromal cells infused into the cerebrospinal fluid promote functional recovery of the injured rat spinal cord with reduced cavity formation. Experimental neurology 2004;187:266-78. [PubMed: 15144853]

8. Wu S, Suzuki Y, Ejiri Y, Noda T, Bai H, Kitada M, et al. Bone marrow stromal cells enhance differentiation of cocultured neurosphere cells and promote regeneration of injured spinal cord. Journal of neuroscience research 2003;72:343-51. [PubMed: 12692901]

9. Fok-Seang J, Smith-Thomas LC, Meiners S, Muir E, Du JS, Housden E, et al. An analysis of astrocytic cell lines with different abilities to promote axon growth. Brain Res 1995;689:207-23. [PubMed: 7583324]

10. Smith-Thomas LC, Stevens J, Fok-Seang J, Faissner A, Rogers JH, Fawcett JW. Increased axon regeneration in astrocytes grown in the presence of proteoglycan synthesis inhibitors. J Cell Sci 1995;108(Pt 3):1307-15. [PubMed: 7622613] 
11. Jones LL, Sajed D, Tuszynski MH. Axonal regeneration through regions of chondroitin sulfate proteoglycan deposition after spinal cord injury: a balance of permissiveness and inhibition. $\mathbf{J}$ Neurosci 2003;23:9276-88. [PubMed: 14561854]

12. Curinga GM, Snow DM, Mashburn C, Kohler K, Thobaben R, Caggiano AO, et al. Mammalianproduced chondroitinase AC mitigates axon inhibition by chondroitin sulfate proteoglycans. J Neurochem. 2007

13. Wang KC, Koprivica V, Kim JA, Sivasankaran R, Guo Y, Neve RL, et al. Oligodendrocyte-myelin glycoprotein is a Nogo receptor ligand that inhibits neurite outgrowth. Nature 2002;417:941-4. [PubMed: 12068310]

14. Kottis V, Thibault P, Mikol D, Xiao ZC, Zhang R, Dergham P, et al. Oligodendrocyte-myelin glycoprotein (OMgp) is an inhibitor of neurite outgrowth. J Neurochem 2002;82:1566-9. [PubMed: 12354307]

15. Huber AB, Schwab ME. Nogo-A, a potent inhibitor of neurite outgrowth and regeneration. Biological chemistry 2000;381:407-19. [PubMed: 10937871]

16. Chen MS, Huber AB, van der Haar ME, Frank M, Schnell L, Spillmann AA, et al. Nogo-A is a myelinassociated neurite outgrowth inhibitor and an antigen for monoclonal antibody IN-1. Nature 2000;403:434-9. [PubMed: 10667796]

17. Liu, BP.; Fournier, A.; GrandPre, T.; Strittmatter, SM. Science. 297. New York, NY: 2002. Myelinassociated glycoprotein as a functional ligand for the Nogo-66 receptor; p. 1190-3.

18. Li S, Kim JE, Budel S, Hampton TG, Strittmatter SM. Transgenic inhibition of Nogo-66 receptor function allows axonal sprouting and improved locomotion after spinal injury. Molecular and cellular neurosciences 2005;29:26-39. [PubMed: 15866044]

19. Yang LJ, Lorenzini I, Vajn K, Mountney A, Schramm LP, Schnaar RL. Sialidase enhances spinal axon outgrowth in vivo. Proceedings of the National Academy of Sciences of the United States of America 2006;103:11057-62. [PubMed: 16847268]

20. Apostolova I, Irintchev A, Schachner M. Tenascin-R restricts posttraumatic remodeling of motoneuron innervation and functional recovery after spinal cord injury in adult mice. $\mathrm{J}$ Neurosci 2006;26:7849-59. [PubMed: 16870730]

21. Becker CG, Becker T, Meyer RL, Schachner M. Tenascin-R inhibits the growth of optic fibers in vitro but is rapidly eliminated during nerve regeneration in the salamander Pleurodeles waltl. $\mathrm{J}$ Neurosci 1999;19:813-27. [PubMed: 9880601]

22. Willerth SM, Arendas KJ, Gottlieb DI, Sakiyama-Elbert SE. Optimization of fibrin scaffolds for differentiation of murine embryonic stem cells into neural lineage cells. Biomaterials 2006;27:59906003. [PubMed: 16919326]

23. Levenberg S, Burdick JA, Kraehenbuehl T, Langer R. Neurotrophin-induced differentiation of human embryonic stem cells on three-dimensional polymeric scaffolds. Tissue engineering 2005;11:50612. [PubMed: 15869429]

24. Levenberg S, Huang NF, Lavik E, Rogers AB, Itskovitz-Eldor J, Langer R. Differentiation of human embryonic stem cells on three-dimensional polymer scaffolds. Proceedings of the National Academy of Sciences of the United States of America 2003;100:12741-6. [PubMed: 14561891]

25. Teng YD, Lavik EB, Qu X, Park KI, Ourednik J, Zurakowski D, et al. Functional recovery following traumatic spinal cord injury mediated by a unique polymer scaffold seeded with neural stem cells. Proceedings of the National Academy of Sciences of the United States of America 2002;99:30249. [PubMed: 11867737]

26. Nomura H, Tator CH, Shoichet MS. Bioengineered strategies for spinal cord repair. J Neurotrauma 2006;23:496-507. [PubMed: 16629632]

27. Basso DM, Beattie MS, Bresnahan JC. A sensitive and reliable locomotor rating scale for open field testing in rats. J Neurotrauma 1995;12:1-21. [PubMed: 7783230]

28. Elisseeff JH. Embryonic stem cells: potential for more impact. Trends in biotechnology 2004;22:1556. [PubMed: 15104108]

29. Polak JM, Bishop AE. Stem cells and tissue engineering: past, present, and future. Annals of the New York Academy of Sciences 2006;1068:352-66. [PubMed: 16831937]

30. Wobus AM, Holzhausen H, Jakel P, Schoneich J. Characterization of a pluripotent stem cell line derived from a mouse embryo. Experimental cell research 1984;152:212-9. [PubMed: 6714319] 
31. Keirstead HS. Stem cell transplantation into the central nervous system and the control of differentiation. Journal of neuroscience research 2001;63:233-6. [PubMed: 11170172]

32. Lee, H.; Al Shamy, G.; Elkabetz, Y.; Schoefield, CM.; Harrsion, NL.; Panagiotakos, G., et al. Stem cells. Dayton, Ohio: 2007. Directed Differentiation And Transplantation of Human Embryonic Stem Cell Derived Motoneurons.

33. Bain G, Kitchens D, Yao M, Huettner JE, Gottlieb DI. Embryonic stem cells express neuronal properties in vitro. Developmental biology 1995;168:342-57. [PubMed: 7729574]

34. Liu S, Qu Y, Stewart TJ, Howard MJ, Chakrabortty S, Holekamp TF, et al. Embryonic stem cells differentiate into oligodendrocytes and myelinate in culture and after spinal cord transplantation. Proceedings of the National Academy of Sciences of the United States of America 2000;97:612631. [PubMed: 10823956]

35. Brustle, O.; Jones, KN.; Learish, RD.; Karram, K.; Choudhary, K.; Wiestler, OD., et al. Science. 285. New York, NY: 1999. Embryonic stem cell-derived glial precursors: a source of myelinating transplants; p. 754-6.

36. McDonald JW, Liu XZ, Qu Y, Liu S, Mickey SK, Turetsky D, et al. Transplanted embryonic stem cells survive, differentiate and promote recovery in injured rat spinal cord. Nature medicine 1999;5:1410-2.

37. Jendelova P, Herynek V, Urdzikova L, Glogarova K, Kroupova J, Andersson B, et al. Magnetic resonance tracking of transplanted bone marrow and embryonic stem cells labeled by iron oxide nanoparticles in rat brain and spinal cord. Journal of neuroscience research 2004;76:232-43. [PubMed: 15048921]

38. Kitagawa A, Nakayama T, Takenaga M, Matsumoto K, Tokura Y, Ohta Y, et al. Lecithinized brainderived neurotrophic factor promotes the differentiation of embryonic stem cells in vitro and in vivo. Biochemical and biophysical research communications 2005;328:1051-7. [PubMed: 15707984]

39. Hendricks, WA.; Pak, ES.; Owensby, JP.; Menta, KJ.; Glazova, M.; Moretto, J., et al. Molecular medicine. 12. Cambridge, Mass: 2006. Predifferentiated embryonic stem cells prevent chronic pain behaviors and restore sensory function following spinal cord injury in mice; p. 34-46.

40. Howard MJ, Liu S, Schottler F, Joy Snider B, Jacquin MF. Transplantation of apoptosis-resistant embryonic stem cells into the injured rat spinal cord. Somatosensory \& motor research 2005;22:3744. [PubMed: 16191756]

41. Chen J, Bernreuther C, Dihne M, Schachner M. Cell adhesion molecule 11-transfected embryonic stem cells with enhanced survival support regrowth of corticospinal tract axons in mice after spinal cord injury. J Neurotrauma 2005;22:896-906. [PubMed: 16083356]

42. Nistor GI, Totoiu MO, Haque N, Carpenter MK, Keirstead HS. Human embryonic stem cells differentiate into oligodendrocytes in high purity and myelinate after spinal cord transplantation. Glia 2005;49:385-96. [PubMed: 15538751]

43. Keirstead HS, Nistor G, Bernal G, Totoiu M, Cloutier F, Sharp K, et al. Human embryonic stem cellderived oligodendrocyte progenitor cell transplants remyelinate and restore locomotion after spinal cord injury. J Neurosci 2005;25:4694-705. [PubMed: 15888645]

44. Faulkner J, Keirstead HS. Human embryonic stem cell-derived oligodendrocyte progenitors for the treatment of spinal cord injury. Transpl Immunol 2005;15:131-42. [PubMed: 16412957]

45. Cloutier F, Siegenthaler MM, Nistor G, Keirstead HS. Transplantation of human embryonic stem cell-derived oligodendrocyte progenitors into rat spinal cord injuries does not cause harm. Regenerative medicine 2006;1:469-79. [PubMed: 17465839]

46. Cao QL, Zhang YP, Howard RM, Walters WM, Tsoulfas P, Whittemore SR. Pluripotent stem cells engrafted into the normal or lesioned adult rat spinal cord are restricted to a glial lineage. Experimental neurology 2001;167:48-58. [PubMed: 11161592]

47. Cao QL, Howard RM, Dennison JB, Whittemore SR. Differentiation of engrafted neuronal-restricted precursor cells is inhibited in the traumatically injured spinal cord. Experimental neurology 2002;177:349-59. [PubMed: 12429182]

48. Enzmann GU, Benton RL, Woock JP, Howard RM, Tsoulfas P, Whittemore SR. Consequences of noggin expression by neural stem, glial, and neuronal precursor cells engrafted into the injured spinal cord. Experimental neurology 2005;195:293-304. [PubMed: 16087174] 
49. Setoguchi T, Nakashima K, Takizawa T, Yanagisawa M, Ochiai W, Okabe M, et al. Treatment of spinal cord injury by transplantation of fetal neural precursor cells engineered to express BMP inhibitor. Experimental neurology 2004;189:33-44. [PubMed: 15296834]

50. Lu P, Jones LL, Snyder EY, Tuszynski MH. Neural stem cells constitutively secrete neurotrophic factors and promote extensive host axonal growth after spinal cord injury. Experimental neurology 2003;181:115-29. [PubMed: 12781986]

51. Ishii K, Nakamura M, Dai H, Finn TP, Okano H, Toyama Y, et al. Neutralization of ciliary neurotrophic factor reduces astrocyte production from transplanted neural stem cells and promotes regeneration of corticospinal tract fibers in spinal cord injury. Journal of neuroscience research 2006;84:1669-81. [PubMed: 17044031]

52. Ziv Y, Avidan H, Pluchino S, Martino G, Schwartz M. Synergy between immune cells and adult neural stem/progenitor cells promotes functional recovery from spinal cord injury. Proceedings of the National Academy of Sciences of the United States of America 2006;103:13174-9. [PubMed: 16938843]

53. Engesser-Cesar C, Anderson AJ, Basso DM, Edgerton VR, Cotman CW. Voluntary wheel running improves recovery from a moderate spinal cord injury. J Neurotrauma 2005;22:157-71. [PubMed: 15665610]

54. Vroemen M, Aigner L, Winkler J, Weidner N. Adult neural progenitor cell grafts survive after acute spinal cord injury and integrate along axonal pathways. The European journal of neuroscience 2003;18:743-51. [PubMed: 12925000]

55. Pfeifer K, Vroemen M, Blesch A, Weidner N. Adult neural progenitor cells provide a permissive guiding substrate for corticospinal axon growth following spinal cord injury. The European journal of neuroscience 2004;20:1695-704. [PubMed: 15379990]

56. Cummings BJ, Uchida N, Tamaki SJ, Salazar DL, Hooshmand M, Summers R, et al. Human neural stem cells differentiate and promote locomotor recovery in spinal cord-injured mice. Proceedings of the National Academy of Sciences of the United States of America 2005;102:14069-74. [PubMed: 16172374]

57. Cummings BJ, Uchida N, Tamaki SJ, Anderson AJ. Human neural stem cell differentiation following transplantation into spinal cord injured mice: association with recovery of locomotor function. Neurol Res 2006;28:474-81. [PubMed: 16808875]

58. Wu P, Tarasenko YI, Gu Y, Huang LY, Coggeshall RE, Yu Y. Region-specific generation of cholinergic neurons from fetal human neural stem cells grafted in adult rat. Nature neuroscience 2002;5:1271-8.

59. Iwanami A, Kaneko S, Nakamura M, Kanemura Y, Mori H, Kobayashi S, et al. Transplantation of human neural stem cells for spinal cord injury in primates. Journal of neuroscience research 2005;80:182-90. [PubMed: 15772979]

60. Tarasenko YI, Gao J, Nie L, Johnson KM, Grady JJ, Hulsebosch CE, et al. Human fetal neural stem cells grafted into contusion-injured rat spinal cords improve behavior. Journal of neuroscience research 2007;85:47-57. [PubMed: 17075895]

61. Woodbury D, Schwarz EJ, Prockop DJ, Black IB. Adult rat and human bone marrow stromal cells differentiate into neurons. Journal of neuroscience research 2000;61:364-70. [PubMed: 10931522]

62. Sanchez-Ramos J, Song S, Cardozo-Pelaez F, Hazzi C, Stedeford T, Willing A, et al. Adult bone marrow stromal cells differentiate into neural cells in vitro. Experimental neurology 2000;164:24756. [PubMed: 10915564]

63. Deng W, Obrocka M, Fischer I, Prockop DJ. In vitro differentiation of human marrow stromal cells into early progenitors of neural cells by conditions that increase intracellular cyclic AMP. Biochemical and biophysical research communications 2001;282:148-52. [PubMed: 11263984]

64. Hofstetter CP, Schwarz EJ, Hess D, Widenfalk J, El Manira A, Prockop DJ, et al. Marrow stromal cells form guiding strands in the injured spinal cord and promote recovery. Proceedings of the National Academy of Sciences of the United States of America 2002;99:2199-204. [PubMed: 11854516]

65. Bakshi A, Barshinger AL, Swanger SA, Madhavani V, Shumsky JS, Neuhuber B, et al. Lumbar puncture delivery of bone marrow stromal cells in spinal cord contusion: a novel method for minimally invasive cell transplantation. J Neurotrauma 2006;23:55-65. [PubMed: 16430372] 
66. Shi E, Kazui T, Jiang X, Washiyama N, Yamashita K, Terada H, et al. Therapeutic benefit of intrathecal injection of marrow stromal cells on ischemia-injured spinal cord. The Annals of thoracic surgery 2007;83:1484-90. [PubMed: 17383362]

67. Khalatbary AR, Tiraihi T. Localization of bone marrow stromal cells in injured spinal cord treated by intravenous route depends on the hemorrhagic lesions in traumatized spinal tissues. Neurol Res 2007;29:21-6. [PubMed: 17427270]

68. Vaquero J, Zurita M, Oya S, Santos M. Cell therapy using bone marrow stromal cells in chronic paraplegic rats: systemic or local administration? Neuroscience letters 2006;398:129-34. [PubMed: $16423458]$

69. Zurita M, Vaquero J. Bone marrow stromal cells can achieve cure of chronic paraplegic rats: functional and morphological outcome one year after transplantation. Neuroscience letters 2006;402:51-6. [PubMed: 16713677]

70. Himes BT, Neuhuber B, Coleman C, Kushner R, Swanger SA, Kopen GC, et al. Recovery of function following grafting of human bone marrow-derived stromal cells into the injured spinal cord. Neurorehabilitation and neural repair 2006;20:278-96. [PubMed: 16679505]

71. Ankeny DP, McTigue DM, Jakeman LB. Bone marrow transplants provide tissue protection and directional guidance for axons after contusive spinal cord injury in rats. Experimental neurology 2004;190:17-31. [PubMed: 15473977]

72. Yano S, Kuroda S, Shichinohe H, Seki T, Ohnishi T, Tamagami H, et al. Bone marrow stromal cell transplantation preserves gammaaminobutyric acid receptor function in the injured spinal cord. J Neurotrauma 2006;23:1682-92. [PubMed: 17115913]

73. Isele NB, Lee HS, Landshamer S, Straube A, Padovan CS, Plesnila N, et al. Bone marrow stromal cells mediate protection through stimulation of PI3-K/Akt and MAPK signaling in neurons. Neurochemistry international 2007;50:243-50. [PubMed: 17050038]

74. Lu P, Jones LL, Tuszynski MH. BDNF-expressing marrow stromal cells support extensive axonal growth at sites of spinal cord injury. Experimental neurology 2005;191:344-60. [PubMed: 15649491]

75. Lu P, Jones LL, Tuszynski MH. Axon regeneration through scars and into sites of chronic spinal cord injury. Experimental neurology 2007;203:8-21. [PubMed: 17014846]

76. Pannucci C, Myckatyn TM, Mackinnon SE, Hayashi A. End-to-side nerve repair: Review of the literature. Restorative neurology and neuroscience 2007;25:45-63. [PubMed: 17473395]

77. Feron F, Perry C, Cochrane J, Licina P, Nowitzke A, Urquhart S, et al. Autologous olfactory ensheathing cell transplantation in human spinal cord injury. Brain 2005;128:2951-60. [PubMed: 16219671]

78. Current Protocols in Cell Biology. John Wiley \& Sons; 1998.

79. Oudega M, Xu XM. Schwann cell transplantation for repair of the adult spinal cord. J Neurotrauma 2006;23:453-67. [PubMed: 16629629]

80. Beattie MS, Bresnahan JC, Komon J, Tovar CA, Van Meter M, Anderson DK, et al. Endogenous repair after spinal cord contusion injuries in the rat. Experimental neurology 1997;148:453-63. [PubMed: 9417825]

81. Blakemore WF. Remyelination of CNS axons by Schwann cells transplanted from the sciatic nerve. Nature 1977;266:68-9. [PubMed: 840300]

82. David, S.; Aguayo, AJ. Science. 214. New York, NY: 1981. Axonal elongation into peripheral nervous system "bridges" after central nervous system injury in adult rats; p. 931-3.

83. Xu XM, Guenard V, Kleitman N, Bunge MB. Axonal regeneration into Schwann cell-seeded guidance channels grafted into transected adult rat spinal cord. The Journal of comparative neurology 1995;351:145-60. [PubMed: 7896937]

84. Xu XM, Guenard V, Kleitman N, Aebischer P, Bunge MB. A combination of BDNF and NT-3 promotes supraspinal axonal regeneration into Schwann cell grafts in adult rat thoracic spinal cord. Experimental neurology 1995;134:261-72. [PubMed: 7556546]

85. Xu XM, Chen A, Guenard V, Kleitman N, Bunge MB. Bridging Schwann cell transplants promote axonal regeneration from both the rostral and caudal stumps of transected adult rat spinal cord. Journal of neurocytology 1997;26:1-16. [PubMed: 9154524] 
86. Imaizumi T, Lankford KL, Kocsis JD. Transplantation of olfactory ensheathing cells or Schwann cells restores rapid and secure conduction across the transected spinal cord. Brain Res 2000;854:708. [PubMed: 10784108]

87. Pinzon A, Calancie B, Oudega M, Noga BR. Conduction of impulses by axons regenerated in a Schwann cell graft in the transected adult rat thoracic spinal cord. Journal of neuroscience research 2001;64:533-41. [PubMed: 11391708]

88. Takami T, Oudega M, Bates ML, Wood PM, Kleitman N, Bunge MB. Schwann cell but not olfactory ensheathing glia transplants improve hindlimb locomotor performance in the moderately contused adult rat thoracic spinal cord. J Neurosci 2002;22:6670-81. [PubMed: 12151546]

89. Menei P, Montero-Menei C, Whittemore SR, Bunge RP, Bunge MB. Schwann cells genetically modified to secrete human BDNF promote enhanced axonal regrowth across transected adult rat spinal cord. The European journal of neuroscience 1998;10:607-21. [PubMed: 9749723]

90. Tuszynski MH, Weidner N, McCormack M, Miller I, Powell H, Conner J. Grafts of genetically modified Schwann cells to the spinal cord: survival, axon growth, and myelination. Cell transplantation 1998;7:187-96. [PubMed: 9588600]

91. Hurtado A, Moon LD, Maquet V, Blits B, Jerome R, Oudega M. Poly (D,L-lactic acid) macroporous guidance scaffolds seeded with Schwann cells genetically modified to secrete a bi-functional neurotrophin implanted in the completely transected adult rat thoracic spinal cord. Biomaterials 2006;27:430-42. [PubMed: 16102815]

92. Chau CH, Shum DK, Li H, Pei J, Lui YY, Wirthlin L, et al. Chondroitinase ABC enhances axonal regrowth through Schwann cell-seeded guidance channels after spinal cord injury. Faseb J 2004;18:194-6. [PubMed: 14630702]

93. Pearse DD, Pereira FC, Marcillo AE, Bates ML, Berrocal YA, Filbin MT, et al. cAMP and Schwann cells promote axonal growth and functional recovery after spinal cord injury. Nature medicine 2004;10:610-6.

94. Ruitenberg MJ, Vukovic J, Sarich J, Busfield SJ, Plant GW. Olfactory ensheathing cells: characteristics, genetic engineering, and therapeutic potential. J Neurotrauma 2006;23:468-78. [PubMed: 16629630]

95. Li, Y.; Field, PM.; Raisman, G. Science. 277. New York, NY: 1997. Repair of adult rat corticospinal tract by transplants of olfactory ensheathing cells; p. 2000-2.

96. Li Y, Field PM, Raisman G. Regeneration of adult rat corticospinal axons induced by transplanted olfactory ensheathing cells. J Neurosci 1998;18:10514-24. [PubMed: 9852589]

97. Keyvan-Fouladi N, Raisman G, Li Y. Functional repair of the corticospinal tract by delayed transplantation of olfactory ensheathing cells in adult rats. J Neurosci 2003;23:9428-34. [PubMed: 14561871]

98. Ramon-Cueto A, Cordero MI, Santos-Benito FF, Avila J. Functional recovery of paraplegic rats and motor axon regeneration in their spinal cords by olfactory ensheathing glia. Neuron 2000;25:42535. [PubMed: 10719896]

99. Lu J, Feron F, Ho SM, Mackay-Sim A, Waite PM. Transplantation of nasal olfactory tissue promotes partial recovery in paraplegic adult rats. Brain Res 2001;889:344-57. [PubMed: 11166728]

100. Garcia-Alias G, Lopez-Vales R, Fores J, Navarro X, Verdu E. Acute transplantation of olfactory ensheathing cells or Schwann cells promotes recovery after spinal cord injury in the rat. Journal of neuroscience research 2004;75:632-41. [PubMed: 14991839]

101. Kato T, Honmou O, Uede T, Hashi K, Kocsis JD. Transplantation of human olfactory ensheathing cells elicits remyelination of demyelinated rat spinal cord. Glia 2000;30:209-18. [PubMed: 10756071]

102. Verdu E, Garcia-Alias G, Fores J, Lopez-Vales R, Navarro X. Olfactory ensheathing cells transplanted in lesioned spinal cord prevent loss of spinal cord parenchyma and promote functional recovery. Glia 2003;42:275-86. [PubMed: 12673833]

103. Plant GW, Christensen CL, Oudega M, Bunge MB. Delayed transplantation of olfactory ensheathing glia promotes sparing/regeneration of supraspinal axons in the contused adult rat spinal cord. J Neurotrauma 2003;20:1-16. [PubMed: 12614584]

104. Ruitenberg MJ, Plant GW, Hamers FP, Wortel J, Blits B, Dijkhuizen PA, et al. Ex vivo adenoviral vector-mediated neurotrophin gene transfer to olfactory ensheathing glia: effects on rubrospinal 
tract regeneration, lesion size, and functional recovery after implantation in the injured rat spinal cord. J Neurosci 2003;23:7045-58. [PubMed: 12904465]

105. Ruitenberg MJ, Levison DB, Lee SV, Verhaagen J, Harvey AR, Plant GW. NT-3 expression from engineered olfactory ensheathing glia promotes spinal sparing and regeneration. Brain 2005;128:839-53. [PubMed: 15716305]

106. Cao L, Liu L, Chen ZY, Wang LM, Ye JL, Qiu HY, et al. Olfactory ensheathing cells genetically modified to secrete GDNF to promote spinal cord repair. Brain 2004;127:535-49. [PubMed: 14691064]

107. Grill R, Murai K, Blesch A, Gage FH, Tuszynski MH. Cellular delivery of neurotrophin-3 promotes corticospinal axonal growth and partial functional recovery after spinal cord injury. J Neurosci 1997;17:5560-72. [PubMed: 9204937]

108. Tuszynski MH, Grill R, Jones LL, McKay HM, Blesch A. Spontaneous and augmented growth of axons in the primate spinal cord: effects of local injury and nerve growth factor-secreting cell grafts. The Journal of comparative neurology 2002;449:88-101. [PubMed: 12115695]

109. Tobias CA, Shumsky JS, Shibata M, Tuszynski MH, Fischer I, Tessler A, et al. Delayed grafting of BDNF and NT-3 producing fibroblasts into the injured spinal cord stimulates sprouting, partially rescues axotomized red nucleus neurons from loss and atrophy, and provides limited regeneration. Experimental neurology 2003;184:97-113. [PubMed: 14637084]

110. Shumsky JS, Tobias CA, Tumolo M, Long WD, Giszter SF, Murray M. Delayed transplantation of fibroblasts genetically modified to secrete BDNF and NT-3 into a spinal cord injury site is associated with limited recovery of function. Experimental neurology 2003;184:114-30. [PubMed: 14637085]

111. McTigue DM, Horner PJ, Stokes BT, Gage FH. Neurotrophin-3 and brain-derived neurotrophic factor induce oligodendrocyte proliferation and myelination of regenerating axons in the contused adult rat spinal cord. J Neurosci 1998;18:5354-65. [PubMed: 9651218]

112. Blesch A, Tuszynski MH. Cellular GDNF delivery promotes growth of motor and dorsal column sensory axons after partial and complete spinal cord transections and induces remyelination. The Journal of comparative neurology 2003;467:403-17. [PubMed: 14608602]

113. Blesch A, Yang H, Weidner N, Hoang A, Otero D. Axonal responses to cellularly delivered NT-4/5 after spinal cord injury. Molecular and cellular neurosciences 2004;27:190-201. [PubMed: 15485774]

114. Pizzi MA, Crowe MJ. Transplantation of fibroblasts that overexpress matrix metalloproteinase- 3 into the site of spinal cord injury in rats. J Neurotrauma 2006;23:1750-65. [PubMed: 17184186]

115. Mahoney MJ, Anseth KS. Three-dimensional growth and function of neural tissue in degradable polyethylene glycol hydrogels. Biomaterials 2006;27:2265-74. [PubMed: 16318872]

116. Mahoney MJ, Anseth KS. Contrasting effects of collagen and bFGF-2 on neural cell function in degradable synthetic PEG hydrogels. Journal of biomedical materials research 2007;81:269-78. [PubMed: 17120204]

117. Taylor SJ, McDonald JW 3rd, Sakiyama-Elbert SE. Controlled release of neurotrophin-3 from fibrin gels for spinal cord injury. J Control Release 2004;98:281-94. [PubMed: 15262419]

118. Taylor SJ, Rosenzweig ES, McDonald JW 3rd, Sakiyama-Elbert SE. Delivery of neurotrophin-3 from fibrin enhances neuronal fiber sprouting after spinal cord injury. J Control Release 2006;113:226-35. [PubMed: 16797770]

119. Taylor SJ, Sakiyama-Elbert SE. Effect of controlled delivery of neurotrophin-3 from fibrin on spinal cord injury in a long term model. J Control Release 2006;116:204-10. [PubMed: 16919351]

120. Willerth, SM.; Faxel, TE.; Gottlieb, DI.; Sakiyama-Elbert, SE. Stem cells. Dayton, Ohio: 2007. The Effects of Soluble Growth Factors on Embryonic Stem Cell Differentiation Inside of Fibrin Scaffolds.

121. Ma W, Fitzgerald W, Liu QY, O'Shaughnessy TJ, Maric D, Lin HJ, et al. CNS stem and progenitor cell differentiation into functional neuronal circuits in three-dimensional collagen gels. Experimental neurology 2004;190:276-88. [PubMed: 15530869]

122. Blesch A, Conner JM, Tuszynski MH. Modulation of neuronal survival and axonal growth in vivo by tetracycline-regulated neurotrophin expression. Gene therapy 2001;8:954-60. [PubMed: 11426336] 
123. Wernig M, Meissner A, Foreman R, Brambrink T, Ku M, Hochedlinger K, et al. In vitro reprogramming of fibroblasts into a pluripotent ES-cell-like state. Nature. 2007

124. Lowry NA, Temple S. Making human neurons from stem cells after spinal cord injury. PLoS medicine 2007;4:e48. [PubMed: 17298166] 


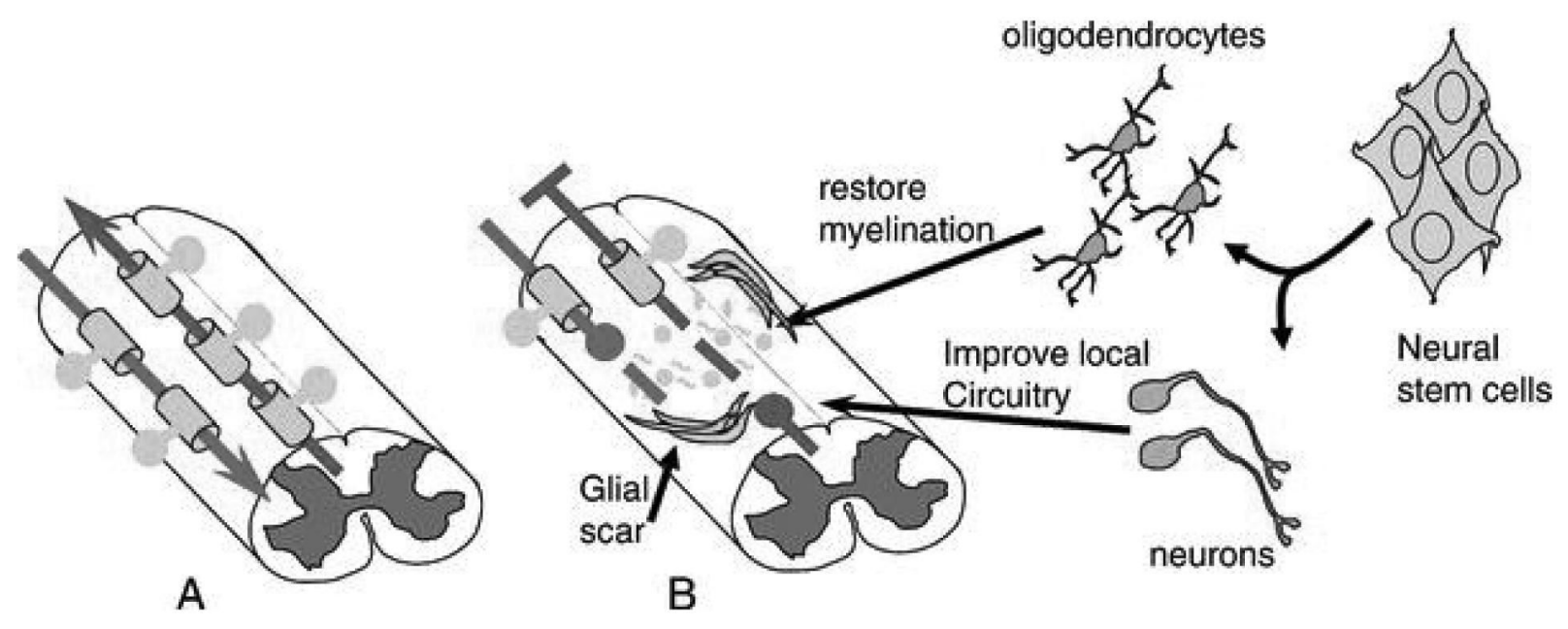

Figure 1.

Comparison of the Uninjured and Injured Spinal Cord. A) Diagram showing uninjured spinal cord containing both ascending and descending tracts of myelinated neurons. B) Diagram showing the injured spinal cord and glial scar along with potential mechanisms of repair through the use of neural stem cell therapy. Reproduced from reference [124], Copyright 2007, Natalia Abramova Lowry and Sally Temple. 
a
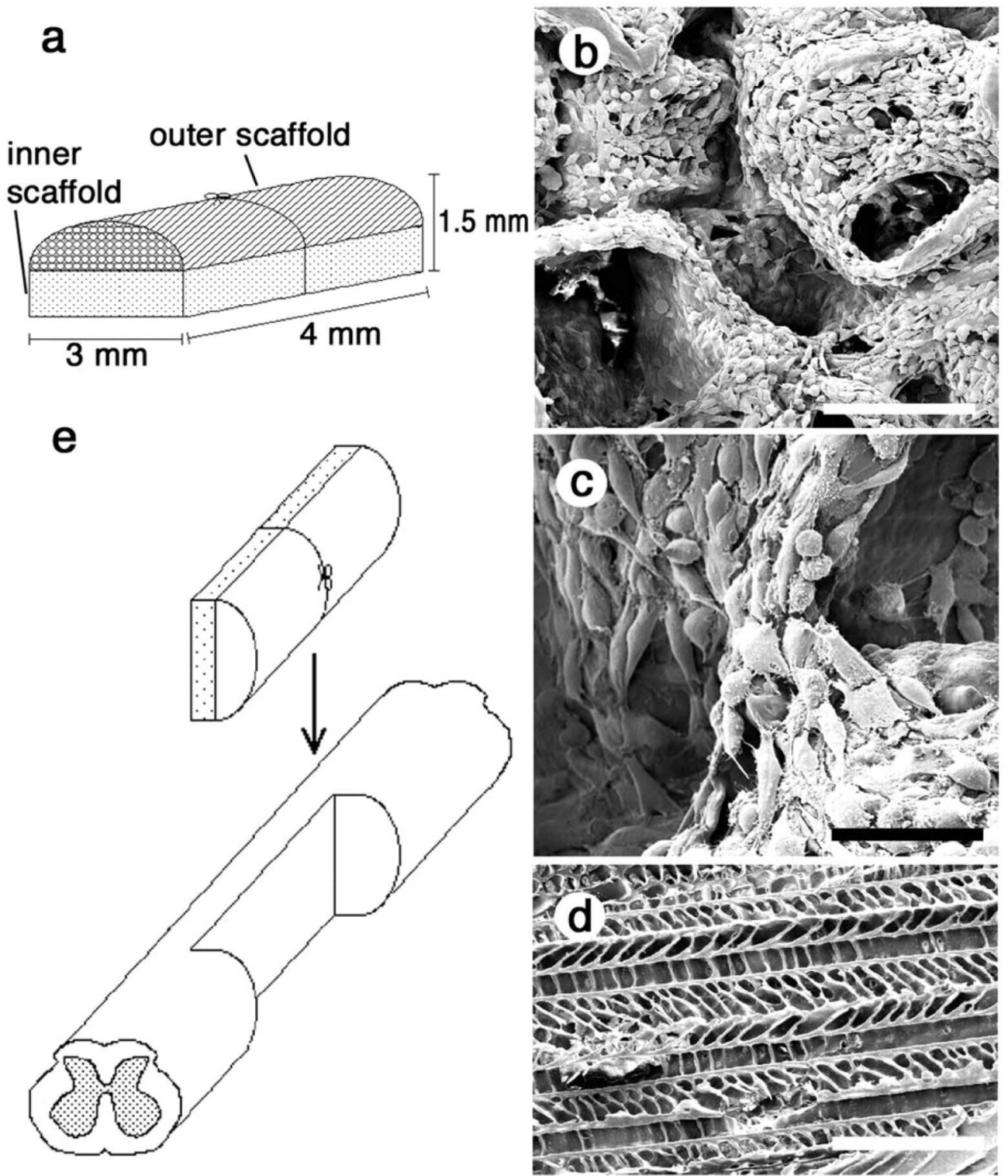

Figure 2.

Biomaterial Scaffolds Seeded with Neural Stem Cells for the Repair of Spinal Cord Injury. A) Schematic of the conduit consisted of inner and outer layers. The inner layer consisted of a porous polymer meant to imitate grey matter while the outer layer emulated the properties exhibited by the white matter with long, axially oriented pores. B) Inner layer of scaffold seeded with NSCs. Scale bar: $200 \mu$ M. C) More detailed look at NSCs seeded in the inner layer of scaffold. Scale bar: $50 \mu \mathrm{M}$. D) Axially oriented pores found in the outer layer of scaffold. Scale bar: $100 \mu \mathrm{M}$. E) Diagram of injury site and placement of scaffold after implantation. Reproduced from reference [25], Copyright 2002, National Academy of Sciences, U.S.A. 
Table One

Cell Types Used As Therapy For Spinal Cord Injury

\begin{tabular}{lll}
\hline Cell Type & References \\
\hline Embryonic Stem Cells & Mouse & \\
& Human & {$[22,33-41,120]$} \\
Neural Stem Cells & & {$[23,24,32,42-45]$} \\
Bone Marrow Stromal Cells & {$[25,46-52,54-57,59,60,115,116,121]$} \\
Mature Cells & Schwann Cells & {$[7,8,61-75]$} \\
& Olfactory Ensheathing Cells & {$[79-93]$} \\
& Fibroblasts & {$[77,94-106]$} \\
& {$[11,107-114,122]$} \\
\hline
\end{tabular}

